\section{Greenhouse talks fail to smoke out US Kyoto strategy}

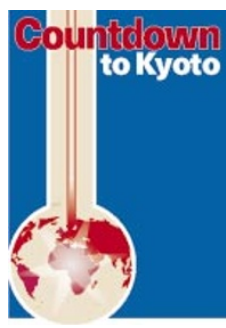

[TOKYO \& LONDON] Two days of separate talks between environment ministers of developed and developing countries ended in Tokyo on Sunday ( 9 November) having achieved little tangible progress towards legally binding targets for greenhouse gas emissions.

Members of the European Union signalled that their proposal to reduce greenhouse gas emissions by 15 per cent by the year 2010 would be negotiable at the climate convention's conference next month in Kyoto. But, despite repeated efforts, the US delegation refused to be drawn on whether its own proposal to stabilize emissions at 1990 levels was similarly 'flexible'.

A parallel meeting of developing countries made virtually no headway. Only two ministers attended, and there were no delegations from China, India or Zimbabwe some saybecause they were unhappy at being segregated from developed countries. "They would have preferred a meeting of all parties on the United Nations model," said one participant.

John Prescott, Britain's deputy prime minister, who chaired the developed country discussion, says he was pleased that countries appear to be moving away from rhetoric. "Every nation and everyone expressed that view," he says. "I think that is a single step forward, because up to now an awful lot of people have been predicting that, whatever the circumstances, they would not cooperate. When you have got a wide difference between zero and fifteen you have got to feel your way through to what is likely to be a realistic figure."

Delegates spent much of the time exploring whether the United States would be prepared to sign up to a higher target for example a 10 per cent reduction in emissions from 1990 levels - achieved through 'joint implementation' and emissions trading.

Again, US delegates would not say whether this proposal was acceptable; according to one European Union participant, it was clear that the United States did not come to Tokyo prepared to talk in detailed terms.

Prescott is to hold separate bilateral meetings with India, Australia and New Zealand. The prime minister of Japan, which chaired the developing country meeting, held negotiations with King Fahd and Crown Prince Abdullah during a visit to Saudi Arabia. AsakoSaegusa\& EhsanMasood

\title{
Russian parliament ratifies chemical weapons treaty
}

[MOsCow] The Russian parliament last week ratified the United Nations convention on chemical weapons, originally signed in Paris in January 1993, despite opposition from critics who complained that Russia cannot afford the costs of destroying its stock of weapons. Soon after, the decree formalizing ratification was signed by President Boris Yeltsin.

Ratification had been actively supported in the Duma, the lower house, by the committee on international affairs and its chairman, Vladimir Lukin, who said that his position was shared by most members of the security and defence committees. The leaders of the factions and deputies' groups — including communists and the Liberal Democratic party - also supported the move.

Igor Ivanov, first deputy minister of foreign affairs, warned that refusal to ratify the convention would be used by Russia's enemies "whose number is still great" as one more reason for the North Atlantic Treaty Organization to move eastwards. Sanctions against Russian exports of chemical products would follow, as well as reduced foreign investment in its chemical industry.

Anatoly Kvashnin, the general staff commander, argued that the greatest threat from Russia's chemical weapons is now to the country itself, rather than its potential enemies, as the storage time of the weapons has long expired. "We need to destroy them to avoid an ecological catastrophe," he said.

But strong opposition to ratification came from the Duma's committee on industry, building, transport and power engineering. Stepan Sulakshin, its deputy chairman,

who was for many years a scientific worker at the Siberian branch of the Russian Academy of Sciences (RAS) in Tomsk, said that destroying all the chemical weapons in Russia would cost 34,400 billion rubles (US\$6 billion).

In 1994 and 1995, when Russia started to meet a presidential commitment to liquidate its chemical weapons, only 9.8 billion and 26.9 billion rubles respectively had been allocated to the task, and in 1996 there was no financing at all. In 1997 only 163.8 billion rubles was allocated.

The proposed budget for 1998 suggests that the equivalent of $\$ 100$ million, rather than the $\$ 500$ million needed, will be allocated. "Russia has no money to destroy its chemical weapons in 10 years, as demanded by the convention," Sulakshin told the Duma. "Foreign countries promised to consider supplying us with a little over $\$ 100$ million after the convention was ratified by Russia, but no agreement has been signed. Under these conditions, the ratification of the convention will ruin Russia."

$\mathrm{He}$ also said that Russia lacks reliable technology for destroying chemical weapons. Until now, the maximum weight of chemical ammunition destroyed at the laboratories was less than 50 grams, while more than 40 tonnes are to be liquidated. The destruction programme has also failed to pass environmental criteria, even though four Duma committees had insisted on this.

"The RAS suggestion to use the economic physical methods of plasma destruction was not adopted," Sulakshin said. But the Duma rejected his arguments and gave its support to the convention.

CarlLevitin

\section{US panel proposes joint 'pathogens initiative'}

[WASHINGTON] The US

Department of Defense (DOD)

should back a collaborative research programme with

Russia on dangerous

pathogens, says a committee of the National Academy of Sciences (NAS) chaired by Nobel laureate Joshua

Lederberg of Rockefeller

University, New York.

The panel says that such a programme would enhance US national security by engaging in joint projects Russian scientists who formerly worked on biological weapons research.
Its findings would lead to

extensive collaboration between biologists at Biopreparat, the body that ran the Russian biological weapons programme, and their counterparts at the US Centers for Disease Control, the US Army Medical Research Institute of Infectious Diseases and US universities.

The committee proposes that the DOD should spend \$38 million over five years on a programme called the Pathogens Initiative, with more than half of the money going to support work in Russia.

The programme would also help the United States to ensure that Russia had stopped all work on biological weapons. Jo Husbands, director of NAS's Committee on International Security and Arms Control, says it is hard to ensure that research on infectious diseases cannot be applied militarily. "But the panel felt that the best insurance we can have is to be engaged with the [Russian] scientists," she says.

Colin Macilwain 